\title{
Inventarisasi Bio-Ekologi Terumbu Karang Di Pulau Panjang, Kabupaten Jepara, Jawa Tengah
}

\author{
Suryono'*, Munasik', R. Ario' dan Gentur Handoyo² \\ 'Departemen IImu Kelautan, Fakultas Perikanan dan IImu Kelautan, Universitas Diponegoro \\ 2Departemen Oseanografi, Fakultas Perikanan dan Ilmu Kelautan, Universitas Diponegoro, \\ JI. Prof. Soedarto, SH. Kampus UNDIP Tembalang, Semarang 50275 \\ Email : suryono1960@gmail.com
}

\begin{abstract}
Inventarization Of Bio-Ecology Of Coral Reef At Panjang Island In Jepara Regency, Central Java
\end{abstract}

The inventarization of coral bioecology is highly needed to identify the real condition of the observed coral, as a database in ecosystem management, as well as an attempt to rehabilitate critical coastal area. Coral condition valuation is conducted by counting the percentage of live coral coverage, by using the Line Intercept Transect method. This research shows that coral condition in Panjang Island falls into moderate category (with 29-49\% of live coral coverage), which represent up to $57 \%$ from total observed area. Coral that falls under "bad" category (live coral coverage below 20\%) is $29 \%$, and only $7 \%$ of the observed area can be categorised as good (more than 50\% coverage) and "very bad" (less than 5\% of coverage). This condition is primarily caused by the decline of water ecology quality caused by sedimentation, west season wave activity, along with human activities like tourism, swimming, fishing, or shellfish gathering. These contributes many instances of coral-breaking caused by gleening.

Keywords : Coral Reef, LIT Methods, Panjang Island, Jepara

\begin{abstract}
Abstrak
Inventarisasi bio-ekogi terumbu karang sangatlah diperlukan guna mengetahui kondisi nyata terumbu karang yang dilakukan pemantauan, sebagai basis data dalam pengelolaan ekosistem serta upaya rehabilitasi kawasan kritis pesisi. Penilaian kondisi terumbu karang dilakukan dengan perhitungan persentase penutupan karang hidup menggunakan metode LIT (Line Intercept Transect). Hasil penelitian menunjukan bahwa Kondisi terumbu karang di Pulau Panjang termasuk dalam kategori sedang (dengan persen tutupan karang hidup 29 - $49 \%$ ) mencapai $57 \%$ dari keseluruhan area pengamatan. Selanjutnya kondisi terumbu karang dengan kategori buruk (persen tutupan karang hidup 20 \%) mencapai $29 \%$ dan hanya $7 \%$ dalam kategori baik (50\%) dan buruk sekali (persen tutupan karang hidup $5 \%$ ). Kondisi tutupan terumbu karang yang relative buruk diduga diakibatkan oleh menurunnya kualitas ekologi perairan yang diakibatkan oleh sedimentasi, aktivitas gelombang musim barat,serta aktivitas manusia seperti wisata, berenang, memancing ataupun pencari kerang turut serta memicu banyaknya pecahan karang akibat terinjak - injak (gleening).
\end{abstract}

Kata Kunci : Terumbu Karang, Metode LIT, Pulau Panjang, Jepara

\section{PENDAHULUAN}

Pulau Panjang yang berada di Pantai Utara Jawa Tengah Kabupaten
Jepara, terletak pada $05^{\circ} 40^{\prime}-05^{\circ} 57^{\prime}$ LS dan $110^{\circ} 04^{\prime}-110^{\circ}-40^{\prime}$ BT secara geografis terletak di Laut Jawa. Luas wilayah teritorial Pulau Panjang 30 Ha. Semakin 
meningkatnya jumlah penduduk dan berkembangnya pemanfatan kawasan pesisir, memberikan dampak pada penekanan ekosistem terumbu karang yang ada di Pulau panjang. Banyaknya aliran sungai yang bermuara di perairan Jepara yang membawa run off daratan dan padatnya aktivitas manusia sehingga menimbulkan tekanan lingkungan terhadap ekosistem terumbu karang di P. Panjang yang ditunjukkan oleh penurunan kondisi ekosistem terumbu karang (Edinger dan Risk, 2000; Indarjo et al, 2004). Terlebih lagi, akhir-akhir ini pemanfaatan Pulau Panjang telah berkembang ke arah wisata pulau, wisata ziarah, dan lokasi penangkapan ikan. Hal ini akan semakin menambah tekanan lingkungan terhadap terumbu karang di P. Panjang. Untuk itu diperlukan upaya yang serius menuju pengelolaan ekosistem Pulau Panjang sebagai penghasil plasma nutfah bagi perairan di Jawa Tengah.

Penelitian tentang terumbu karang telah banyak dilakukan di perairan $P$. Panjang terutama menyangkut struktur komunitas,mauapun populasi. Namun belum dapat memberikan gambaran tentang kondisi terumbu pada skala luas sehingga dapat digunakan sebagai acuan dalam pembentukan zona pengelolaan terumbu karang. Studi kondisi terumbu karang di P. Panjang guna perencanaan pengelolaan menerapkan penilaian kondisi terumbu karang yang tepat.

\section{MATERI DAN METODE}

Penelitian dan pengamatan kondisi terumbu karang ini dilaksanakan pada November tahun 2011 serta tahun 2013 di perairan Pulau Panjang, di tujuh stasiun yang berbeda dan pada 2 kedalaman ( $3 \mathrm{~m}$ dan $7 \mathrm{~m}$ ) di masing-masing stasiun (Lihat Gambar 1).Materi penelitian adalah koloni karang hidup yang ditemukan di perairan Pulau Panjang.Penelitian menggunakan metode survey, yaitu metode penelitian yang diadakan untuk memperoleh fakta - fakta dari gejalagejala yang ada dan mencari keterangan-keterangan secara faktual (Nazir, 1992). Penelitian ini bersifat studi kasus yaitu penelitian terhadap suatu kasus secara mendalam yang hanya berlaku pada waktu, tempat dan populasi terbatas dan hasilnya tidak dapat digeneralisasikan untuk tempat dan waktu berbeda (Hadi, 1993).Metode Pengambilan Data Kondisi Terumbu Karang di perairan ditentukan melalui perhitungan persentase penutupan karang hidup. Kriteria kondisi terumbu karang ditentukan oleh nilai persentase penutupan karang hidup bedasarkan Gomez dan Yapp (1988) sebagaimana tercantum dalam Tabel 1.

Penutupan karang hidup diketahui dengan menggunakan transek garis menyinggung (Line Intercept Transect). Transek garis sepanjang $50 \mathrm{~m}$ dibentangkan pada setiap stasiun di Pulau Panjang pada kedalaman 3 dan $7 \mathrm{~m}$. Pencatatan panjang tutupan karang dan biota yang berasosiasi dengan karang yang terdapat di bawah meteran hingga ketelitian $\mathrm{cm}$.Setiap koloni karang yang ditemukan berada di bawah transect di identifikasi hingga tingkat genus.Persentase penutupan karang hidup digunakan sebagai acuan dalam menentukan kondisi terumbu karang. Karang batu merupakan unsur paling dominant di dalam ekosistem terumbu karang sehingga persentase penutupannya digunakan untuk menentukan kondisi terumbu karang (Sukarno, 1995)

Tabel 1. Kriteria penilaian kondisi terumbu karang berdasarkan persentase penutupan karang

\begin{tabular}{cl}
\hline $\begin{array}{c}\text { Persentase Penutupan } \\
\text { Karang }(\%)\end{array}$ & $\begin{array}{c}\text { Kondisi Terumbu } \\
\text { Karang }\end{array}$ \\
\hline$<25$ & Buruk \\
$25-50$ & Sedang \\
$50-75$ & Baik \\
$>75$ & Sangat baik \\
\hline
\end{tabular}

Sumber. Gomez dan Yapp (1988)

Data yang diperoleh dianalisa menggunakan metode deskriptif yaitu dengan menggambarkan hasil yang telah diperoleh dan didukung dengan membandingkan tabulasi dari pengolahan data. Perhitungan mengenai persentase karang hidup juga dilakukan 


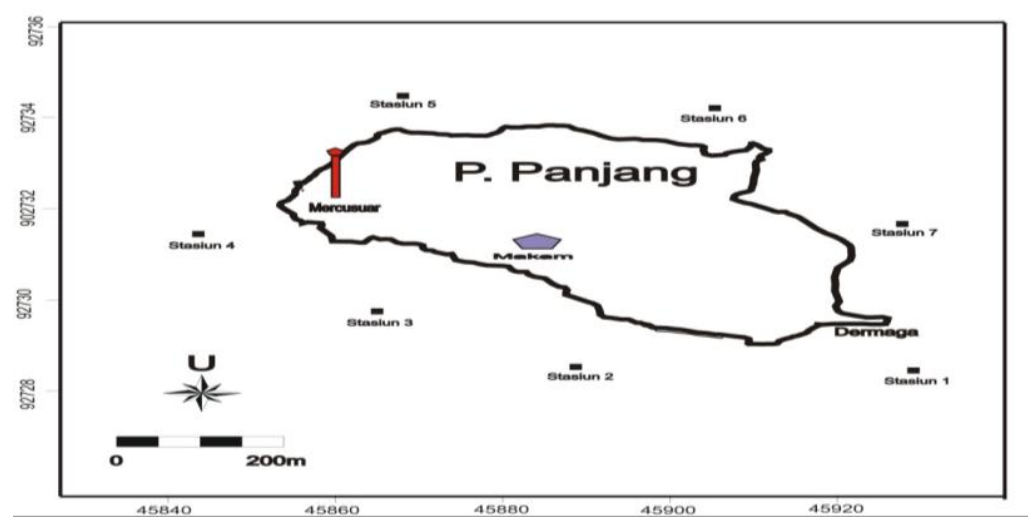

Gambar 1. Lokasi Stasiun Pemantauan Kondisi Terumbu Karang di Pulau Panjang Kab. Jepara

untuk menentukan kondisi terumbu karang di daerah tersebut. Persentase penutupan karang hidup ditentukan dengan rumus sebagai berikut (English et.al., 1994):

$$
n i=\frac{l i}{L} x 100 \%
$$

Dimana:

$\mathrm{ni}=$ Persentase penutupan karang hidup (\%)

li = Panjang koloni karang per panjang transek garis $(\mathrm{cm})$

$\mathrm{L}=$ Panjang transek garis $(\mathrm{m})$

\section{HASIL DAN PEMBAHASAN}

Kondisi terumbu karang di Pulau Panjang Kabupaten Jepara yang ditunjukkan oleh tutupan karang hidup (Hard Coral Live/HCL) di sekeliling pulau bervariasi dari kategori buruk sekali hingga baik (Gambar 2). Secara umum, kondisi terumbu karang di P. Panjang termasuk dalam kategori sedang (dengan persen tutupan karang hidup 25-49\%) mencapai $57 \%$ dari seluruh area pengamatan. Selanjutnya kondisi terumbu dengan kategori buruk (persen tutupan karang hidup $20 \%$ ) mencapai $29 \%$ dan hanya $7 \%$ dalam kategori baik (50\%) dan buruk sekali (persen tutupan karang hidup 5\%). Bagian terumbu karang di P. Panjang yang termasuk dalam kategori buruk sekali tersebut bukan karena mengalami kerusakan akan tetapi substrat di wilayah pengamatan didominasi oleh pasir dengan tutupan hingga $95 \%$.

Persentase tutupan karang hidup di P. Panjang tertinggi pada terumbu karang sisi barat laut Pulau Panjang, di sekitar depan Mercusuar (Towing ke-5 dan 6) yaitu berkisar $40-50 \%$ sedangkan tutupan karang hidup lebih rendah yaitu $40 \%$ di terumbu karang sisi utara. Hasil pengamatan menunjukkan bahwa tinggi rendahnya tutupan karang hidup di $P$. Panjang berkaitan dengan tingkat kematian koloni karang. Terumbu dengan persen tutupan karang hidup yang tinggi diikuti oleh persen tutupan karang mati dan batu karang yang rendah. Terumbu karang di depan Mercusuar dengan persen tutupan tertinggi memiliki Indeks Mortalitas (MI) rendah yaitu 0,2 sedangkan terumbu karang di depan Makam (Towing ke- 1) dengan persen tutupan $20 \%$ memiliki Indeks Mortalitas (MI) yang tinggi yaitu 2. Hanya satu lokasi pengamatan dengan persen tutupan yang sangat rendah dengan Indeks Mortalitas karang (MI) bernilai 0 yaitu di terumbu karang sisi utara (Towing ke-11), terumbu karang hanya tersusun atas karang hidup. Proses kematian karang keras dimulai dari gejala bleaching, kemudian substrat keras terumbu ditumbuhi karang lunak .

Secara umum kerusakan terumbu karang yang terjadi di Pulau Panjang berupa karang mati dari karang massive dan branching. Kerusakan pada karang massive berupa karang mati ditumbuhi alga yang dipicu oleh penyakit karang. Kejadian tersebut diduga diakibatkan oleh menurunnya kualitas perairan akibat sedimentasi. Sedangkan, kerusakan pada karang bercabang (branching) ditemukan 
berupa pecahan karang (rubble) dari genus Acropora. Pecahan karang paling banyak ditemukan di dataran terumbu bagian selatan pulau. Kerusakan tersebut diduga diakibatkan oleh aktivitas gelombang musim barat. Selain itu, aktivitas manusia seperti wisata, berenang, memancing ataupun pencari kerang turut serta memicu banyaknya pecahan karang akibat terinjak - injak (gleening). Ancaman lainnya adalah ketika musim barat, dimana pada bagian timur digunakan sebagai tempat berlindung kapal-kapal besar.

Terumbu karang di Pulau Panjang, Kab. Jepara umumnya memiliki tingkat kerusakan tergolong rendah yaitu kerusakan tingkat 1. Kerusakan rendah terumbu karang tersebut ditandai oleh terdapatnya penyakit karang, melimpahnya makro alga dan ditemukannya bulu babi (Diadema) sehingga kemungkinan perairan sudah terjadi pengkayaan bahan organik (Edinger et al., 1998). Namun karena terumbu karang di P. Panjang terbentuk atas 2 bagian yaitu dataran terumbu dan lereng terumbu maka hal ini dapat menimbulkan perbedaan kondisi ekosistem dan tingkat kerusakan terumbu karang yang berbeda. Kerusakan dataran terumbu karang yang dangkal biasanya ditimbulkan oleh aktivitas manusia saat berjalan-jalan diatas karang dan koloni

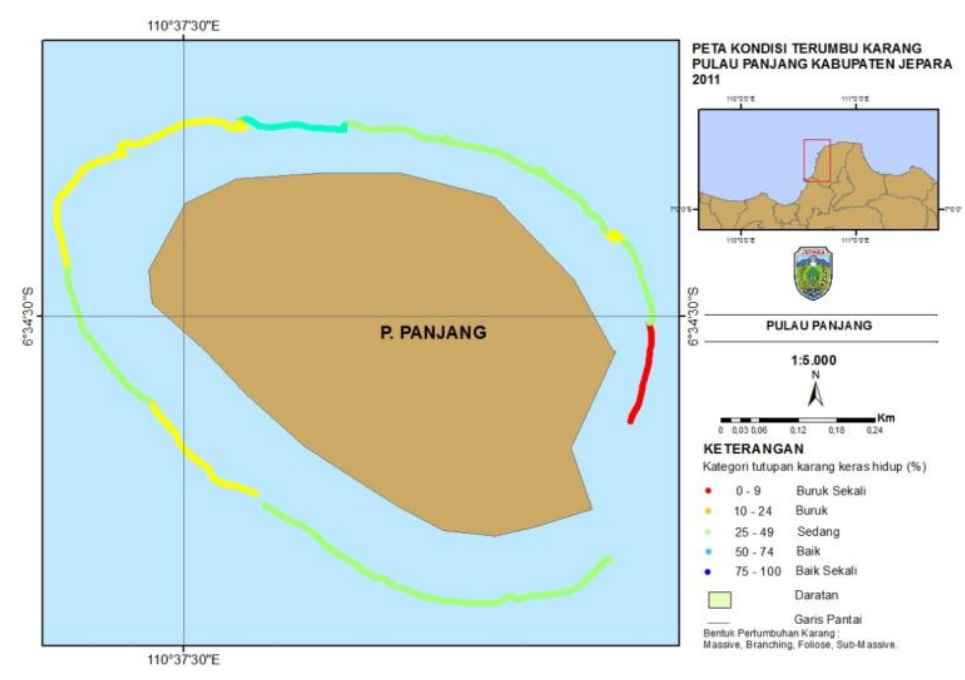

Gambar 2. Kondisi terumbu karang di Pulau Panjang, Kab. Jepara

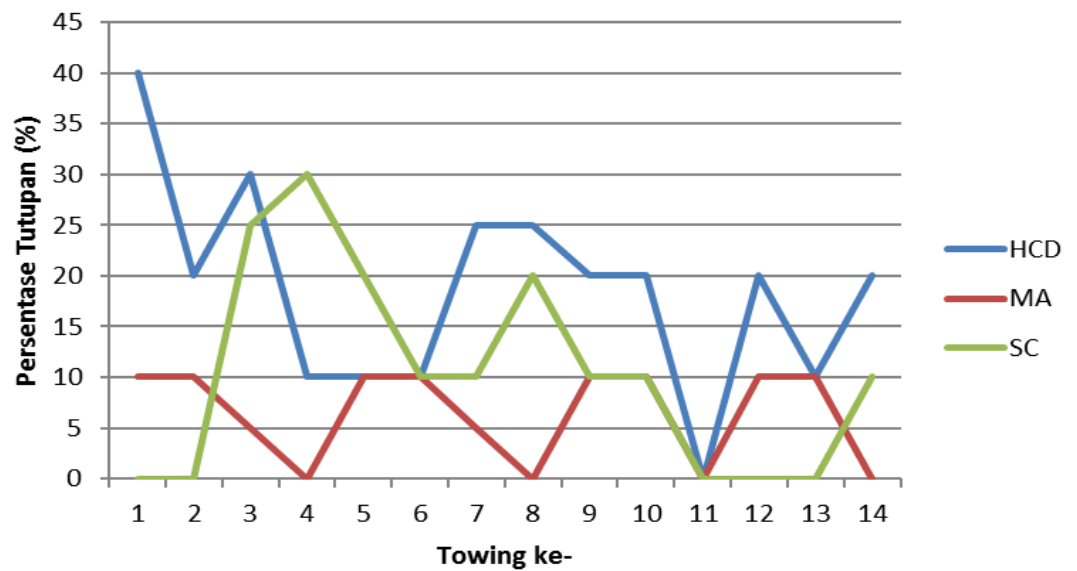

Gambar 3. Hubungan persentase tutupan Karang Mati (HCD), Makro Alga (MA) dan Karang Lunak (SC) di Pulau Panjang, Kab. Jepara 
yang terpapar udara sewaktu surut terendah (Munasik, unpublished data). Sebaliknya kerusakan pada bagian lereng terumbu dengan kemiringan 10-20 umumnya akibat siltasi (kekeruhan) atau resuspensi endapan sedimen substrat dasar akibat gelombang atau arus. Sebagaimana diketahui bahwa perairan $P$. Panjang selalu mendapatkan sumbangan sedimen tersuspensi pada saat hujan yang berasal dari sungai-sungai dari daratan P. Jawa yang bermuara ke perairan Jepara dan berpotensi mengancam kelestarian terumbu karang (Munasik et al., 2000; Indarjo et al, 2004). Lain hal, pemanfaatan P. Panjang untuk berbagai kegiatan seperti wisata pulau, wisata ziarah, tempat memancing dan pengangkapan perikanan pantai juga turut menyumbang ancaman kerusakan.

Berdasarkan hasil observasi tahun 2013, kondisi ekosistem terumbu karang yang ada di perairan Pulau Panjang mengalami peningkatan kerusakan yang tinggi dari tahu ke tahun. Hal ini disebabkan oleh beberapa hal, diantarannya adalah adanya penambangan ilegal terumbu karang yang dilakukan oleh para masyarakat pesisir. Kerusakan berikutnya disebabkan oleh aktifitas pemancing di sekitar sisi barat, utara dan selatan. Berdasarkan hasil wawancara dengan responden, pemancing yang melakukan pemancingan disekitar perairan Pulau Panjang menginjak-injak karang pada saat memancing.

\section{KESIMPULAN}

Inventarisasi kondisi terumbu karang di perairan Pulau panjang menunjukan bahwa kondisi terumbu karang termasuk dalam kategori sedang sampai dengan kategori buruk. Kondisinya cenderung mengalami penurunan dari tahun ke tahun (2011 sampai dengan 2013), disebabkan oleh 2 faktor, yaitu faktor gangguan dari alam dan gangguan dari aktifitas kegiatan manusia (anthropogenic). Untuk itu pengaturan pemanfaatan melalui pengelolaan yang lebih serius perlu segera di lakukan.

\section{DAFTAR PUSTAKA}

Edinger, E.N., J. Jompa, G.V Limmon, W. Widjatmoko, and M.J. Risk. 1998. Reef degradation and coral biodiversity in Indonesia: effects of landbased pollution, destructive fishing practices, and changes over time. Mar. Poll. Bull. 36:617-630.

Edinger, E.N and M.J. Risk. 2000. Reef classification by coral morphology predicts coral reef conservation value. Biologic. Conservation 92: 1-13

English, S.C., Wilkinson and Baker. 1994. Survey Manual For Tropical Marine Resources. Australian Institute of Marine Sciences. Townville Australia 368p.

Gomez, E.D. and. H.T. Yap.Monitoring Reef Condition ,p 171-178. In R.A. Kenchington and B.E.T. Hudson (Eds). Coral Reef Management Handbook. Unesco Regional Office For Science and Technology for Southeast Asia. Jakarta

Hadi, Sutrisno.1993. Metode Penelitian. Gajahmada Press. Yogyakarta

Indarjo, A., W. Widjatmoko dan Munasik. 2004. Kondisi terumbu karang di perairan Pulau Panjang, Jepara. Jurnal Ilmu Kelautan, 9 (4): 217-224.

Munasik, W Widjatmoko, E Soefriyanto, dan $S$ Sejati. 2000. Struktur Komunitas Karang Hermatipik di Perairan Jepara. Jurnal Ilmu Kelautan. 19(V): 217-224

Nazir, Moh. 2005. Metode Penelitian. Ghalaia Indonesia Publisher. Bogor. Indonesia. $544 \mathrm{Hal}$

Sukarno, R. 1995 Ekosistem Terumbu Karang Dan Masalah Pengelolaannya. Makalah Disampaikan Dalam Kursus Pelatihan Metodologi Penelitian Penentuan Kondisi Terumbu Karang. Pusat Penelitian dan Pengembangan Oseanologi. LIPI Jakarta. $14 \mathrm{Hal}$. 